\title{
Catfish Egg Lectin Causes Rapid Activation of Multidrug Resistance 1 P-Glycoprotein as a Lipid Translocase
}

\author{
Shigeki Sugawara, Masahiro Hosono, Yukiko Ogawa, Motoaki TakaYanagi, and Kazuo Nitta* \\ Cancer Research Institute, Tohoku Pharmaceutical University; 4-4-1 Komatsushima, Aoba-ku, Sendai 981-8558, Japan. \\ Received November 21, 2004; accepted December 8, 2004
}

\begin{abstract}
Rhamnose-binding lectin from catfish (Silurus asotus) eggs (SAL) has the ability to induce externalization of phosphatidylserine (PS), followed by cell shrinkage in globotriaosylceramide (Gb3)-expressing Burkitt's lymphoma Raji cells. Because phospholipid scramblase and aminophospholipid translocase did not participate in SAL-induced PS externalization, we examined the relationship of ATP-binding cassette (ABC) transporters, such as multidrug resistance (MDR) 1 P-glycoprotein (MDR1 P-gp) and MDR-associated protein 1 (MRP1), for translocation of PS. Since cyclosporin A (MDR1 P-gp inhibitor) but not MK571 (MRP1 inhibitor) inhibited SAL-induced PS externalization, it was suggested that MDR1 P-gp is involved in this phenomenon. On the other hand, SAL activated both of the ABC transporters for efflux of rhodamine123 (MDR1 P-gp substrate, Rho123) and 5-carboxyfluorescein diacetate (MRP1 substrate, 5-CFDA) in Raji cells. In contrast, SAL did not activate these two transporters in Gb3-negative cell lines, such as $\mathrm{K562}$ and doxorubicin-resistant $\mathrm{K562}$ cells, involving not only PS externalization but also efflux of Rho123 or 5-CFDA. Since Gb3 and both transporters in Raji cells are located in the glycosphingolipid-enriched microdomain (GEM), it is suggested that the binding of SAL to Gb3 localized in the GEM specifically induces MDR1 P-gp activation in Raji cells.
\end{abstract}

Key words rhamnose-binding lectin; phosphatidylserine; annexin V; lipid translocation; multidrug resistance (MDR)1 P-glycoprotein; glycosphingolipid-enriched microdomain

Apoptotic cells are characterized based on biologic and morphologic features, such as externalization of phosphatidylserine (PS), activation of caspase, fragmentation of chromosomal DNA, cell shrinkage, plasma membrane blebbing, and nuclear condensation. ${ }^{1-5)}$ Plasma membrane phospholipids are normally asymmetrically distributed, with phosphatidylcholine (PC) and sphingomyelin located in the outer leaflet, and PS and phosphatidylethanolamine (PE) restricted to the inner leaflet. ${ }^{6}$ It is well known that a rapid bidirectional movement of plasma membrane phospholipids between the two leaflets is catalyzed by phospholipid scramblase (PLS), aminophospholipid translocase (APTL), and ATP-binding cassette (ABC) transporter multidrug resistance (MDR) 1 P-glycoprotein (MDR1 P-gp). ${ }^{7-9)}$ Treatment of cells with various apoptosis inducers causes transbilayer movement of phospholipids, resulting in the externalization of PS and PE on the cell surface. ${ }^{10-12)}$ Cytotoxic galactose (Gal)-binding lectins such as ricin, abrin, and misletoe lectin ultimately cause apoptosis through PS externalization and other apoptotic events. ${ }^{13-15)}$ On the other hand, human dimeric galectin-1 (dGal-1) induces PS externalization but not apoptosis. ${ }^{16)}$ The molecular mechanisms of PS externalization induced by these lectins are still unclear and appear to be different.

In our previous studies, we demonstrated that: 1) catfish (Silurus asotus) lectin (SAL) is a $32-\mathrm{kDa}$ protein and consists of three tandem repeat domains of 95 amino acid residues $^{17)}$; 2) SAL has potent affinity for L-rhamnose and melibiose (Gal $\alpha 1-6 \mathrm{Glc}$ ) and belongs to the rhamnose-binding lectin family ${ }^{18)}$; 3) SAL recognizes Gal $\alpha$-linked carbohydrate chains of glycoproteins as well as those of glycosphingolipids (GSLs) such as globotriaosylceramide (Gb3) (Hosono M., Sugawara S., Ogawa Y., Hikita T., Ambo A., Sasaki Y., Takayanagi M., Hakomori S., Nitta K., unpublished observation); and 4) SAL agglutinates Gb3-expressing Burkitt's lymphoma cells, such as Raji and Daudi cells. ${ }^{19-21)}$
In this study, we used Gb3-expressing Raji cells to investigate whether: 1) SAL causes an increase in annexin $\mathrm{V}$ binding as reflected by PS externalization and a decrease in cell volume; 2) SAL leads to activation of MDR1 P-gp, causing translocation of PS from inner to outer leaflets; and 3) Gb3 and MDR1 P-gp are colocalized in the GSL-enriched microdomain (GEM).

\section{MATERIALS AND METHODS}

Materials SAL was isolated in sequential chromatography on a DE23 (Whatman) anion-exchange column and Dgalactose-Sepharose $6 \mathrm{~B}$ column as described previously. ${ }^{18)}$ Antiserum against SAL was prepared in rabbits (Japanese white) with Freund's incomplete adjuvant, as described previously. ${ }^{17)}$

Cell Culture The Burkitt's lymphoma Raji cell line was obtained from the Cell Resource Center of the Biomedical Research, Institute of Development, Ageing and Cancer, Tohoku University (Sendai, Japan). Human erythroleukemia K562 cells were obtained from the Japanese Cancer Research Resources Bank (Tokyo, Japan). Doxorubicin-resistant K562 (K562/DXR) cells were a gift from Dr. Masaaki Ishikawa (Tohoku Pharmaceutical University, Sendai, Japan). These cells were cultured in RPMI 1640 medium (Nissui Pharmaceutical Co. Ltd., Tokyo, Japan) supplemented with $10 \%$ fetal calf serum (FCS), penicillin $(100 \mathrm{U} / \mathrm{ml})$, and streptomycin $(100 \mu \mathrm{g} / \mathrm{ml})$ and maintained at $37^{\circ} \mathrm{C}$ in a $95 \%$ air and $5 \% \mathrm{CO}_{2}$ atmosphere.

Flow Cytometric Analysis of Annexin V Binding and Propidium Iodide Incorporation Cells $\left(1 \times 10^{5}\right)$ were treated with or without SAL $[100 \mu \mathrm{l} ; 2.5,5.0$, and $10 \mu \mathrm{g} / \mathrm{ml}$ Dulbecco's phosphate-buffered saline (D-PBS)] at $4{ }^{\circ} \mathrm{C}$ for 5 , 10, 20, and $30 \mathrm{~min}$. Apoptosis was detected using a MEBCYTO apoptosis kit (MBL, Nagoya, Japan) with a flow cytometer, FACScan (Becton Dickinson, Franklin Lakes, NJ, 
U.S.A.) with a single laser emitting excitation light at $488 \mathrm{~nm} .^{1,22)}$

Measurement of Inhibition of SAL-Induced PS Externalization The inhibition assay of SAL-induced PS externalization was performed in the following manner. ${ }^{23)}$ Cells $\left(2 \times 10^{5}\right)$ were treated with $4 \mu \mathrm{M}$ of cyclosporin A (CsA, MDR1 Pgp inhibitor; Sigma, St. Louis, MO, U.S.A.) at $37^{\circ} \mathrm{C}$ for $40 \mathrm{~h}$, or $80 \mu \mathrm{M}$ of MK571 (MRP1 inhibitor; Cayman Chemical, Ann Arbor, MI, U.S.A.) at $37^{\circ} \mathrm{C}$ for $60 \mathrm{~min}$. After washing, the cells were treated with or without SAL $(100 \mu$, $10 \mu \mathrm{g} / \mathrm{ml} \mathrm{D}$-PBS) at $4{ }^{\circ} \mathrm{C}$ for $30 \mathrm{~min}$. PS externalization was detected using the MEBCYTO apoptosis kit (MBL) described above.

Flow Cytometric Analysis of Cell Size Cells $\left(2 \times 10^{5}\right)$ were incubated with or without SAL $(100 \mu 1,2.5,5.0$, and $10 \mu \mathrm{g} / \mathrm{ml} \mathrm{D}$-PBS) at $4{ }^{\circ} \mathrm{C}$ for $5,10,20$, and $30 \mathrm{~min}$. Cell size was measured from forward scatter light values using FACScan (Becton Dickinson).

Measurement of PLS and APTL Activities PLS: PLS activity was measured as the uptake of fluorescence-labeled phospholipid 1-palmitoyl-1-[6-[(7-nitro-2-1,3-benzoxadiazol-4-yl)amino]dodecanoyl]-PC (NBD-PC) (Avanti PolarLipids, Inc., Alabaster, AL, U.S.A.). ${ }^{24)}$ SAL-treated or -untreated cells $\left(5 \times 10^{5}\right)$ were washed once and resuspended in HEPES-buffered saline (HBS; $\mathrm{NaCl} 137 \mathrm{~mm}, \mathrm{KCl} 2.7 \mathrm{~mm}$, $\mathrm{MgCl}_{2} 2 \mathrm{~mm}$, HEPES $10 \mathrm{~mm}$, pH 7.4, containing $\mathrm{CaCl}_{2} 1 \mathrm{~mm}$ ) $(50 \mu \mathrm{l})$. The cell suspensions were incubated with NBD-PC $(1 \mu \mathrm{l}, 50 \mu \mathrm{g} / \mathrm{ml})$ and propidium iodide (PI) $(2.5 \mu \mathrm{l}$, $100 \mu \mathrm{g} / \mathrm{ml}$ ) for $10 \mathrm{~min}$ at room temperature, followed by back-extraction with $1 \%$ bovine serum albumin (BSA) in HBS $(50 \mu \mathrm{l})$ for an additional $5 \mathrm{~min}$. After the samples were transferred to an ice bath, ice-cold HBS $(900 \mu \mathrm{l})$ was added, and the fluorescence values were analyzed with FACScan.

APTL: APTL activity was measured as the uptake of NBD-PS (Avanti Polar-Lipids, Inc.) into SAL- or $N$-ethylmaleimide-treated cells $\left(5 \times 10^{5}\right)$ in the same manner as described above. ${ }^{25)}$

Analysis of mRNA Expression in Reverse Transcription-PCR Total cellular RNA was isolated from cells $\left(1 \times 10^{7}\right)$ using an RNeasy mini kit (Qiagen Inc., Valencia, CA, U.S.A.). Reverse transcription (RT) was performed using ReverTra Ace (Toyobo, Osaka, Japan) with total RNA $(1 \mu \mathrm{g})$ and oligo $(\mathrm{dT})_{20}$ primers. Then the RT reaction mixture $(1 \mu \mathrm{l})$ was subjected to PCR for 25 or 30 cycles in a final volume of $25 \mu \mathrm{l}$ of Taq DNA polymerase (1.25 U, Promega, Madison, WI, U.S.A.) and MDR1, MDR2, MDR-associated protein 1 (MRP1), and G3PDH gene-specific primers as follows: MDR1 (forward: 5CCCATCATTGCAATAGCAGG3, reverse: 5GTTCAAACTTCTGCTCCTGA3) ${ }^{26)}$; MDR2 (forward: 5GCTGTGTCAGGAATTGTTGA3, reverse: 5TCGAAAACAACCGGCATAGG3) ${ }^{26)}$; MRP1 (forward: 5CACTGAATGGCATCACCTTC3, reverse: 5CTTCTCGCCAATCTCTGTCC3) ${ }^{27)}$; G3PDH (forward: 5ACCACAGTCCATGCCATCAC3, reverse: 5TCCACCACCCTGTTGCTGTA3). ${ }^{28)}$ After initial denaturation at $94^{\circ} \mathrm{C}$ for $2 \mathrm{~min}$, each cycle was composed of at $94^{\circ} \mathrm{C}$ for $30 \mathrm{~s}, 60^{\circ} \mathrm{C}$ for $30 \mathrm{~s}$, and $72^{\circ} \mathrm{C}$ for $30 \mathrm{~s}$. PCR amplification products were separated on $1.5 \%$ agarose gel. Bands were visualized with ethidium bromide staining.

Flow Cytometric Analysis of ABC Transporter Proteins MDR1 P-gp: Cells $\left(1 \times 10^{5}\right)$ were treated with biotin- labeled P-gp-reactive MRK16 monoclonal antibody (mAb) (Kyowa Medex, Tokyo, Japan) at a dilution of 1:5 in D-PBS $(50 \mu \mathrm{l})$ at $4{ }^{\circ} \mathrm{C}$ for $30 \mathrm{~min}$, washed twice with D-PBS, and then reacted with fluorescein isothiocyanate (FITC)-conjugated streptavidin (Invitrogen, Groningen, the Netherlands) at a dilution of $1: 150$ in D-PBS $(100 \mu \mathrm{l})$ at $4{ }^{\circ} \mathrm{C}$ for $30 \mathrm{~min}$. The degree of MDR1 P-gp expression was analyzed using FACScan.

MRP1: Cells $\left(1 \times 10^{6}\right)$ were fixed in $4 \%$ paraformaldehyde in D-PBS for $15 \mathrm{~min}$ at room temperature, washed twice with D-PBS, and permeated with $0.2 \%$ Triton X-100 in D-PBS for $10 \mathrm{~min}$ at room temperature. The permeated cells were treated with anti-MRP1 rat mAb (MRPr1; Kamiya Biomedical Company, Seattle, WA, U.S.A.) at a dilution of $1: 20$ in D-PBS $(100 \mu \mathrm{l})$ at $4{ }^{\circ} \mathrm{C}$ for $30 \mathrm{~min}$, washed twice with D$\mathrm{PBS}$, and reacted with FITC-conjugated rat secondary $\mathrm{Ab}$ (Cedarlane, Ontario, Canada) at a dilution of $1: 1000$ in DPBS $(100 \mu \mathrm{l})$ at $4^{\circ} \mathrm{C}$ for $30 \mathrm{~min}$. The degree of MRP1 expression was analyzed in the same manner as described above.

Detection of MDR1 P-gp- and MRP1-Mediated Drug Efflux in FACS Analysis The drug efflux assay was performed in the following way. ${ }^{23,29)} \mathrm{K} 562$, K562/DXR, and Raji cells $\left(1 \times 10^{5}\right)$ were suspended in RPMI-1640 medium and incubated in the presence of rhodamine123 (Rho123) $1 \mu \mathrm{M}$ or 5-carboxyfluorescein diacetate (5-CFDA, Sigma) $0.5 \mu \mathrm{M}$ at $37^{\circ} \mathrm{C}$ for $60 \mathrm{~min}$. After washing, Rho123- and 5CFDA-loaded cells were suspended in RPMI 1640 medium and incubated in the presence or absence of cyclosporin A $20 \mu \mathrm{M}$ and MK571 $80 \mu \mathrm{M}$ at $37^{\circ} \mathrm{C}$ for $60 \mathrm{~min}$, respectively. After washing with D-PBS, single-cell fluorescence was quantified using flow cytometry.

To evaluate the effect of SAL against $\mathrm{ABC}$ transportermediated drug efflux, Rho123- and 5-CFDA/MK571-loaded cells were treated with or without SAL $(100 \mu \mathrm{l}, 10 \mu \mathrm{g} / \mathrm{ml} \mathrm{D}$ PBS) at $4{ }^{\circ} \mathrm{C}$ for $30 \mathrm{~min}$. 5-CFDA/MK571-loaded cells were prepared by the incubation of 5-CFDA-loaded cells with MK571 for the preservation of 5-CFDA in the cells. The residual amounts of Rho123 and 5-CFDA and cell size were analyzed using flow cytometry.

Preparation of the GEM The GEM was prepared according to the method of Hakomori and Handa. ${ }^{30)}$ Briefly, cells $\left(2 \times 10^{7}\right)$ were harvested in D-PBS and centrifuged. Pelleted cells were suspended in $1 \mathrm{ml}$ of Triton X-100 lysis buffer [Tris- $\mathrm{HCl} 10 \mathrm{~mm}(\mathrm{pH} 7.5)-\mathrm{NaCl} 15 \mathrm{~mm}-$ EDTA $5 \mathrm{~mm}$ (TNE) containing 1\% Triton X-100, phenylmethanesulufonyl fluoride (PMSF) $2 \mathrm{~mm}$ and aprotinin $75 \mathrm{U}$, and incubated for $30 \mathrm{~min}$ on ice. Then the cell suspension was homogenized in a Dounce homogenizer with a tight-fitting piston for 10 strokes, and the homogenate was centrifuged for $5 \mathrm{~min}$ at $1300 \times \boldsymbol{g}$. The supernatant fraction was subjected to sucrose density-gradient centrifugation. One milliliter of this fraction was mixed with $1 \mathrm{ml}$ of $85 \%$ sucrose $(\mathrm{w} / \mathrm{v})$ in TNF. The resulting diluent $(2 \mathrm{ml})$ was placed at the bottom of a $12-\mathrm{ml}$ centrifuge tube, $5.5 \mathrm{ml}$ of $35 \%$ sucrose in TNE was overlain, and then $4 \mathrm{ml}$ of $5 \%$ sucrose in TNE was further overlain. Tubes were centrifuged at $39000 \mathrm{rpm}$ in a Beckman SW40Ti rotor at $4{ }^{\circ} \mathrm{C}$ for $17 \mathrm{~h}$ without interruption. A series of $1-\mathrm{ml}$ aliquots was collected from the top to bottom of the tube to yield a total of 12 fractions. The light-scattering band corresponding to the GEM was usually located at fraction 4 or 5 . 
Sodium Dodecyl Sulfate-Polyacrylamide Gel Electrophoresis and Western Blot Analysis All fractions obtained from sucrose density-gradient centrifugation were separated by sodium dodecyl sulfate-polyacrylamide gel electrophoresis (SDS-PAGE) in 7\% gel ${ }^{31)}$ and transferred electrophoretically to a polyvinylidene difluoride (PVDF) membrane (Hybond $\mathrm{P}$ from Amersham Biosciences, Uppsala, Sweden) in transfer buffer (Tris $25 \mathrm{~mm}$, glycine $192 \mathrm{~mm}$ containing $15 \%$ methanol) at $200 \mathrm{~mA}$ for $4 \mathrm{~h}$ at $\left.4{ }^{\circ} \mathrm{C} .{ }^{32}\right)$ The membrane was blocked with $5 \%$ nonfat, dry milk in Trisbuffered saline (TBS) at $4{ }^{\circ} \mathrm{C}$ overnight.

MDR1 P-gp and MRP1: After washing with TBS containing $0.05 \%$ Tween 20 (TBS-T), the blocked membranes were incubated with anti-MDR1 mouse mAb C219 (Signet Laboratories, Inc., Dedham, MA, U.S.A.) at a dilution of $1: 100$ in TBS-T containing $0.5 \%$ nonfat, dry milk (TBS-Tb) for detection of MDR1 P-gp and MRPr1 at a dilution of $1: 50$ in TBS-Tb for detection of MRP1 at room temperature for $2 \mathrm{~h}$, respectively. After extensive washing with TBS-T, the membranes were reacted with horseradish peroxidase (HRP)-conjugated anti-mouse IgG (Cedarlane) at a dilution of $1: 4000$ in TBS-Tb for MDR1 P-gp and HRP-conjugated anti-rat IgG (Santa Cruz Biotechnology, Inc., Santa Cruz, CA, U.S.A.) a dilution of $1: 4000$ in TBS-Tb for MRP1 at room temperature for $2 \mathrm{~h}$, respectively. After washing with TBS-T, the target molecules on the membrane were detected using an ECL Western blotting detection kit (Amersham Biosciences).

Statistical Analysis Results are reported as the mean of percentage \pm standard error (S.E.) of the mean. Two-tailed Student's $t$-tests or ANOVA were used as appropriate for statistical analysis. Only $p$ values $<0.05$ were considered to be statistically significant.

\section{RESULTS AND DISCUSSION}

SAL Causes PS Externalization, Followed by Cell Shrinkage in Raji Cells PS externalization and cell shrinkage are known to be early apoptotic events. ${ }^{1,33)}$ To elucidate which event occurs first in SAL-induced cascade reactions, we analyzed the relationship of annexin V binding, PI incorporation, and cell shrinkage with changes in the concentration and timing of SAL treatment. The increase in cell populations of lower right-hand (LR) quadrant [annexin $\mathrm{V}$ $(+) / \mathrm{PI}(-)$ ] and upper right-hand (UR) quadrant [annexin V $(+) / \mathrm{PI}(+)]$ was dependent on SAL concentration and time (Fig. 1, Table 1). When Raji cells were treated with SAL $5 \mu \mathrm{g} / \mathrm{ml}$ for $10 \mathrm{~min}$ at $4{ }^{\circ} \mathrm{C}$, the population in the LR quadrant reached the maximum level $(33.10 \%)$ (Table 1$)$. The decrease in the LR quadrant cell population treated with SAL $5 \mu \mathrm{g} / \mathrm{ml}$ for periods from 10 to $20 \mathrm{~min}$ was apparently only $3.7 \%$, and decrements in the lower left-hand (LL) quadrant [annexin $\mathrm{V}(-) / \mathrm{PI}(-)](12.99 \%, p<0.05)$ corresponded to increments in the UR quadrant $(16.80 \%, p<0.05)$, i.e., there is a turning point for periods for up to $20 \mathrm{~min}$ after $10 \mathrm{~min}$. SAL-induced cell shrinkage was barely observed up to SAL $5 \mu \mathrm{g} / \mathrm{ml}$ for $5 \mathrm{~min}$ (7.15-fold) (Fig. 1B). Since a remarkable increase of greater than $50 \%$ in shrunken cells was observed in the population in the UR quadrant (e.g., treatment with SAL $5 \mu \mathrm{g} / \mathrm{ml}$ for $20 \mathrm{~min}$ or longer, see Fig. 1B), it was suggested that cell shrinkage occurred after PS externalization.

Annexin V bound to SAL-treated Raji cells (Fig. 1A), but not to SAL-treated K562 and K562/DXR cells. PI was also incorporated in SAL-treated Raji cells (Fig. 1A), but not in SAL-treated K562 and K562/DXR cells (data not shown, see Table 2). While treatment of Raji cells with SAL increased PI incorporation (Fig. 1A), no loss of membrane intactness was seen in the trypan blue dye-exclusion assay (data not shown). ${ }^{34)}$ These results suggest that treatment with SAL accelerates incorporation of PI by living Raji cells.

Dias-Baruffi et al. ${ }^{16)}$ reported that: 1) dGal-1 and monomeric mutant Gal-1 (mGal-1) strongly bound to neuraminidase-treated HL-60 and MOLT- 4 cells, but weakly to intact HL-60 and MOLT-4 cells; 2) dGal-1 induced PS externalization in intact HL-60 and MOLT-4 cells and neuraminidase treatment of the cells enhanced their sensitivity to dGal-1;3) mGal-1 did not induce PS externalization even in desialylated cells; and 4) no change was observed in the cell size of dGal-1-treated cells, resulting in the failure to induce apoptosis. Although SAL as well as dGal-1 induced increased annexin $\mathrm{V}$ binding (Fig. 1A), but did not execute apoptosis, SAL caused a cell volume decrease (Fig. 1B) that was different from that of dGal-1. Since dGal-1 bound to Gal $\beta$-linked carbohydrate chains on desialylated tumor cells and activated neutrophils, the binding specificity of dGal-1 appears to be to a broad spectrum of cell types. Because SAL did not recognize sialic acid on carbohydrate chains, SAL selectively bound to $\mathrm{Gb} 3$-expressing tumor cells without neuraminidase treatment.

SAL Activates MDR1 P-gp for PS Externalization in Raji Cells PLS, APTL, and ABC transporters are known to be molecules maintaining or regulating the plasma membrane transbilayer phospholipid distribution. ${ }^{7-9,35)}$ To identify the molecule inducing PS externalization, we examined their expression at the mRNA and protein levels. Raji cells expressed very low levels of PLS1, while this protein was detected in K562 and Jurkat cells (data not shown, see Table 2). ${ }^{7,25,36)}$ In addition, we were unable to determine the uptake of exogenous NBD-PC facilitated by PLS, because there was no detectable amount of NBD-PC (data not shown, see Table 2). Since Raji cells express very high levels of APTL, which moves PS and PE from the outer to inner leaflet of the plasma membrane, ${ }^{25,37)}$ we measured the uptake of exogenous NBD-PS to determine APTL activity. Although $N$-ethylmaleimide (thiol-reactive agent, inhibitor of APTL) blocked translocation not only of endogenous PS but also of NBD-PS in Raji cells, resulting in induction of PS externalization, ${ }^{25)}$ no decrease in APTL activity was observed in SAL-treated Raji cells (data not shown, see Table 2). Because PLS and APTL did not participate in the SAL-induced PS externalization described above, we tested the involvement of $\mathrm{ABC}$ transporters in the translocation of PS. It is well known that K562/DXR cells have higher MDR1 P-gp expression than chemosensitive K562 cells. ${ }^{38)}$ As shown in Fig. 2A, MDR1 P-gp mRNA was detected in K562/DXR cells, but not in K562 cells. In the case of Raji cells, we detected a very faint band of MDR1 P-gp mRNA. On the other hand, equal MRP1 mRNA expression was detected in all three cell lines.

When K562/DXR cells were treated with MRK16 mAb, MDR1 P-gp expression was observed with cytometric analysis (Fig. 2B). However, there was no detectable amount of MDR1 P-gp in either Raji cells or K562 cells. Since the level 
$\boldsymbol{A}$
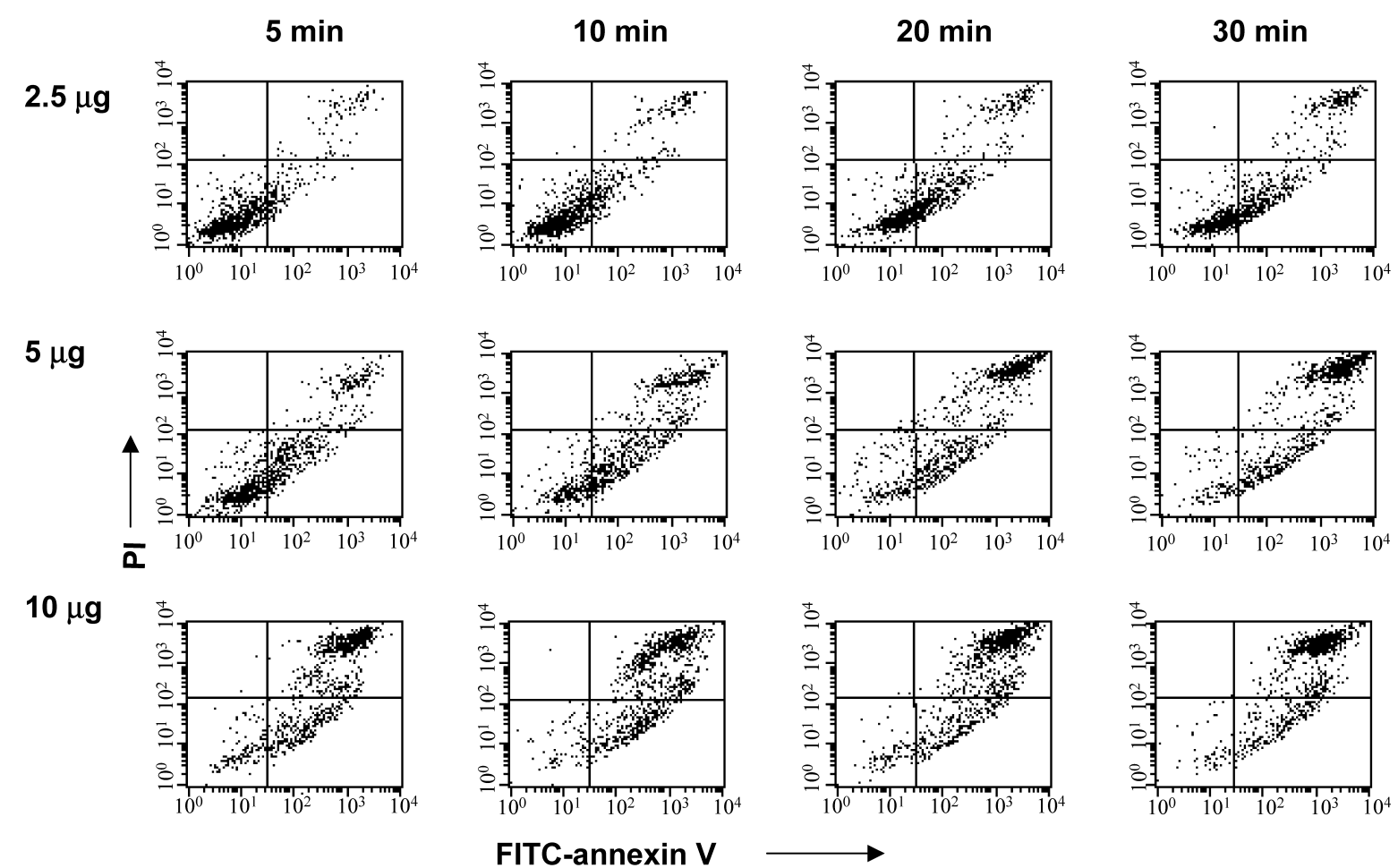

B

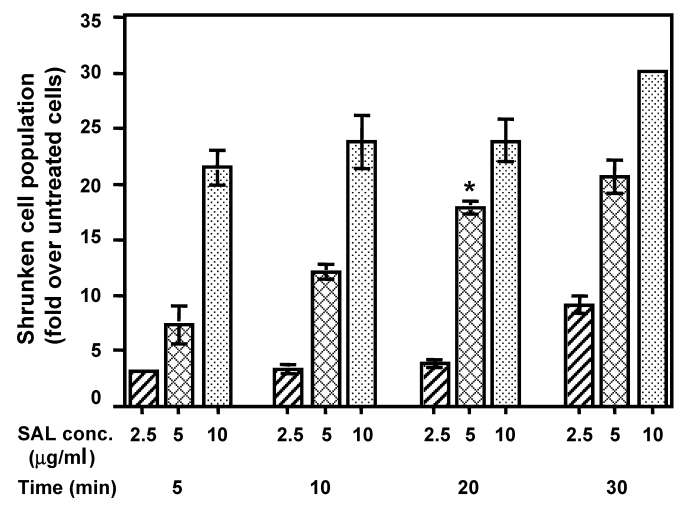

Fig. 1. Time- and Dose-Dependent Changes in FITC-Annexin V Binding, PI Incorporation, and Cell Size in SAL-Treated Raji Cells

Raji cells were treated with SAL $(2.5,5.0,10 \mu \mathrm{g} / \mathrm{ml})$ at $4{ }^{\circ} \mathrm{C}$ for $5,10,20$, and $30 \mathrm{~min}$. (A) PS externalization and PI incorporation were detected using the MEBCYTO apoptosis kit with FACScan. Treatment of Raji cells with SAL showed an increase in the percentage of cells divided into the lower right-hand (LR) quadrant [annexin V (+)/PI $(-)]$ and upper right-hand (UR) quadrant [annexin V (+)/PI (+)], respectively. Data are representative of at least three independent experiments performed in triplicate. Although this figure is a typical pattern of dot plots, the percentages of cells divided into the lower left-hand (LL) quadrant [annexin V (-)/PI (-)], LR quadrant, and UR quadrant are shown in Table 1. (B) Cell size measured from forward scatter light values using FACScan. The ratio of shrunken cells in SAL-untreated cells was $3.0 \%$. The increment in the shrunken cell population in SAL-treated cells is indicated in multiples of number converted 3.0 into 1. Each value represents the mean \pm S.E. of three independent experiments performed in triplicate. $* p<0.05$ versus treatment with SAL $5 \mu \mathrm{g} / \mathrm{ml}$ for $10 \mathrm{~min}$.

of MDR1 P-gp mRNA expression was very slight in Raji cells (Fig. 2A), we could not detect MDR1 P-gp on the surface of Raji cells using MRK16 mAb (Fig. 2B). On the other hand, the amount of MRP1 derived from K562/DXR cells was nearly equal to that from Raji cells and K562 cells (Fig. 2B).

To elucidate whether MDR1 P-gp participates in SAL-induced PS externalization, we pretreated Raji cells with MDR1 P-gp inhibitor $(\mathrm{CsA})^{23)}$ or MRP1 inhibitor (MK571). ${ }^{39)}$ Although treatment of Raji cells with SAL at $4{ }^{\circ} \mathrm{C}$ for $30 \mathrm{~min}$ caused an increase in the percentage of cells divided into the LR quadrant $(14.46 \%)$ and UR quadrant (77.92\%), pretreatment with CsA decreased the population in the UR quadrant from $77.92 \%$ to $58.03 \%$ (19.89\% reduction, $p<0.05)$ and increased the sum of the population in the LL and LR quadrants from $21.60 \%$ to $41.31 \%$ (19.71\% increase, $p<0.05$ ) (Fig. 3). On the other hand, no change in the population in the LR and UR quadrants was observed with MK571 pretreatment (Fig. 3). Since CsA but not MK571 inhibited SAL-induced PS externalization, it was suggested that MDR1 P-gp is involved in this phenomenon. CsA is known to prevent the mitochondrial permeability transition (MPT) and swelling ${ }^{40)}$ and to block tumor necrosis factor $\alpha$ induced apoptosis and cytochrome $\mathrm{C}$ release. ${ }^{41)}$ Although the influence of intracellular signaling amplified by SAL on MPT is still not known, the inhibition of SAL-induced PS externalization by CsA may involve the prevention of the MPT. 
Table 1. Changes in Annexin V-Bound and PI-Incorporated Cell Population

\begin{tabular}{|c|c|c|c|c|}
\hline \multirow{2}{*}{$\begin{array}{l}\text { SAL conc. } \\
(\mu \mathrm{g} / \mathrm{ml})\end{array}$} & \multirow{2}{*}{$\begin{array}{l}\text { Time } \\
(\mathrm{min})\end{array}$} & \multicolumn{3}{|c|}{ Population of LL-, LR-, and UR-quadrant (\%) } \\
\hline & & LL & LR & UR \\
\hline Control & & $90.74 \pm 0.77$ & $4.31 \pm 0.51$ & $4.79 \pm 0.35$ \\
\hline \multirow[t]{4}{*}{2.5} & 5 & $79.07 \pm 1.75$ & $12.91 \pm 0.88$ & $7.90 \pm 0.89$ \\
\hline & 10 & $69.12 \pm 0.21$ & $17.68 \pm 1.33$ & $14.38 \pm 1.74$ \\
\hline & 20 & $56.87 \pm 3.62$ & $29.21 \pm 3.12$ & $15.09 \pm 0.53$ \\
\hline & 30 & $47.47 \pm 1.26$ & $27.91 \pm 1.68$ & $24.33 \pm 0.32$ \\
\hline \multirow[t]{4}{*}{5} & 5 & $48.24 \pm 2.03$ & $29.08 \pm 2.43$ & $22.07 \pm 2.53$ \\
\hline & 10 & $33.06 \pm 3.90 *$ & $33.10 \pm 1.77$ & $33.32 \pm 2.47 *$ \\
\hline & 20 & $20.07 \pm 0.04 * *$ & $29.40 \pm 0.98$ & $50.12 \pm 0.91 * *$ \\
\hline & 30 & $16.09 \pm 2.03$ & $26.64 \pm 1.60$ & $56.88 \pm 2.35$ \\
\hline \multirow[t]{4}{*}{10} & 5 & $17.49 \pm 5.56$ & $24.95 \pm 2.96$ & $54.30 \pm 2.98$ \\
\hline & 10 & $10.63 \pm 3.06$ & $26.58 \pm 0.65$ & $62.42 \pm 2.51$ \\
\hline & 20 & $9.64 \pm 1.89$ & $24.90 \pm 0.31$ & $64.79 \pm 1.89$ \\
\hline & 30 & $5.67 \pm 0.81$ & $16.70 \pm 1.80$ & $77.25 \pm 2.46$ \\
\hline
\end{tabular}

Each value represents the mean \pm S.E. of three independent experiments performed in triplicate. $* p<0.05(48.24 \pm 2.03$ and $22.07 \pm 2.53$ for $5 \mu \mathrm{g} / \mathrm{ml}, 5 \mathrm{~min}$ versus $33.06 \pm 3.90$ and $33.32 \pm 2.47$ for $5 \mu \mathrm{g} / \mathrm{ml}, 10 \mathrm{~min}$, respectively); and $* * p<0.05(33.06 \pm 3.90$ and $33.32 \pm 2.47 \mathrm{for} 5 \mu \mathrm{g} / \mathrm{ml}, 10 \mathrm{~min}$ versus $20.07 \pm 0.04$ and $50.12 \pm 0.91 \mathrm{for} 5 \mu \mathrm{g} / \mathrm{ml}, 20 \mathrm{~min}$, respectively)

Table 2. SAL-Induced PS Externalization and Related Molecules

\begin{tabular}{|c|c|c|c|c|}
\hline & Raji & K562 & K562/DXR & Jurkat \\
\hline Gb3 expression & Positive ${ }^{20,21)}$ & Negative $^{20,21)}$ & Negative & Negative $^{21)}$ \\
\hline SAL binding $\left.^{a}\right)$ & Yes & No & No & No \\
\hline PS externalization $^{a}$ ) & Yes & No & No & No \\
\hline PI incorporation ${ }^{a)}$ & Yes & No & No & No \\
\hline Cell shrinkage $^{a)}$ & Yes & No & No & No \\
\hline PLS1 activity & Very low ${ }^{7,26,37)}$ & Medium $^{7)}$ & $\mathrm{NT}^{b)}$ & $\operatorname{High}^{7,26,37)}$ \\
\hline APTL activity & Very high ${ }^{26,38)}$ & Negative ${ }^{38)}$ & NT & Low $^{26)}$ \\
\hline MDR1 P-gp mRNA & Very faint ${ }^{c)}$ & Negative $^{c)}$ & Very high $^{c)}$ & NT \\
\hline protein & Very faint $^{d \text { ) }}$ & Negative $^{d)}$ & Very high $^{d}$ & \\
\hline MDR2/3 P-gp mRNA & Negative $^{c)}$ & Negative $^{c)}$ & Negative ${ }^{c)}$ & NT \\
\hline MRP1 mRNA & $\operatorname{High}^{c)}$ & $\operatorname{High}^{c)}$ & $\operatorname{High}^{c)}$ & NT \\
\hline protein & $\operatorname{High}^{d)}$ & $\left.\operatorname{High}^{d}\right)$ & $\left.\operatorname{High}^{d}\right)$ & \\
\hline
\end{tabular}

a) SAL binding, PS externalization (see Fig. 1A), PI incorporation (see Fig. 1A), and cell shrinkage (see Fig. 1B) were induced by SAL (yes) or no SAL (no). $b$ ) Not tested. c) mRNA expression evaluated by RT-PCR (see Fig. 2A). d) Western blot analysis of samples obtained by sucrose density-gradient centrifugation (see Fig. 4). Superscript numbers, reference numbers.

B MDR1 P-gp

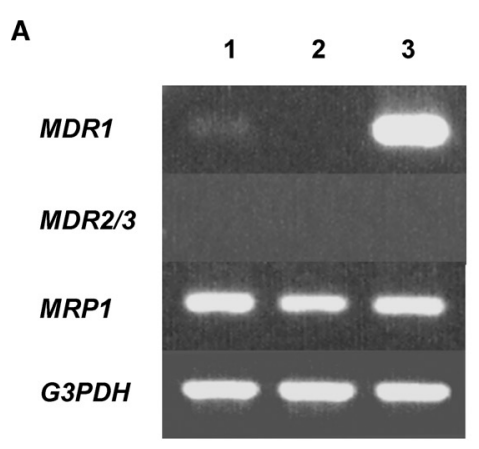

Raji

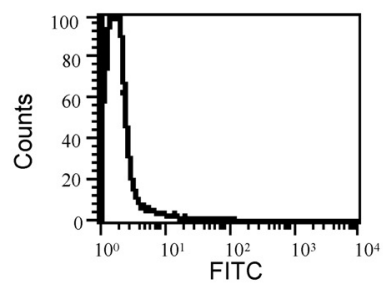

MRP1

Raji

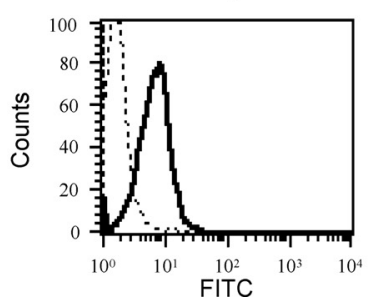

K562

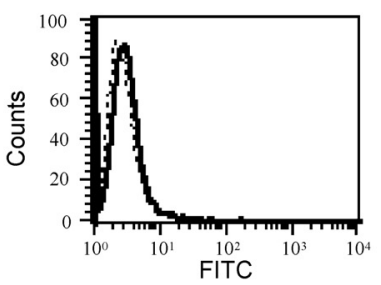

K562

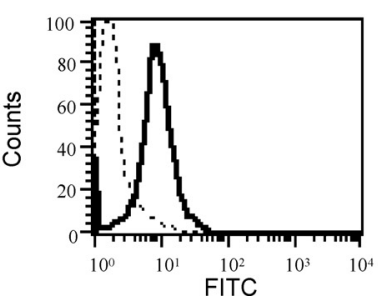

K562/DXR

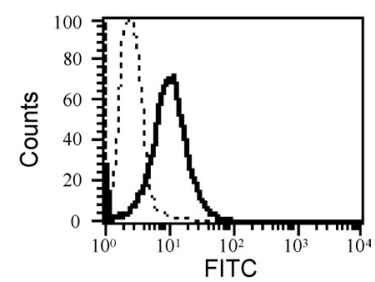

K562/DXR

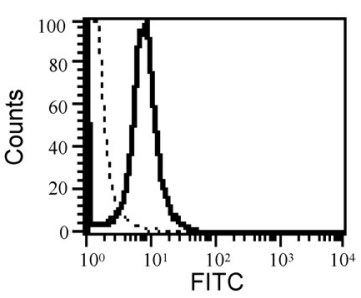

Fig. 2. Expression of ABC Transporter Genes and Proteins in Raji, K562, and K562/DXR Cells

(A) After RNA was extracted from Raji, K562, or K562/DXR cells, RT-PCR was performed using specific primers for MDR1, MDR2/3, MRP1, and G3PDH as described in the text, respectively. Lane 1, Raji cells; lane 2, K562 cells; lane 3, K562/DXR cells. (B) Expression of MDR1 P-gp and MRP1 was assessed using FACScan. Cells were treated with biotin-labeled MRK16 mAb directed against MDR1 P-gp or MRPr1 rat mAb directed against MRP1. Then FITC-conjugated streptoavidin and FITC-conjugated anti-rat IgG were used as secondary Abs, respectively. Dotted line, fluorescence intensity of control cells. 

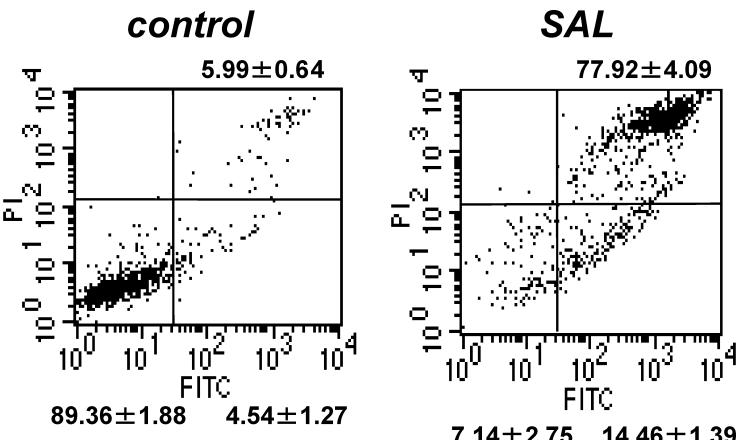

CsA/SAL

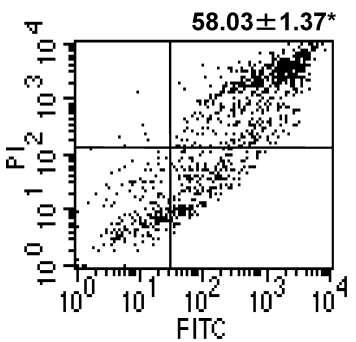

$18.56 \pm 2.24^{*} 22.75 \pm 0.66^{*}$

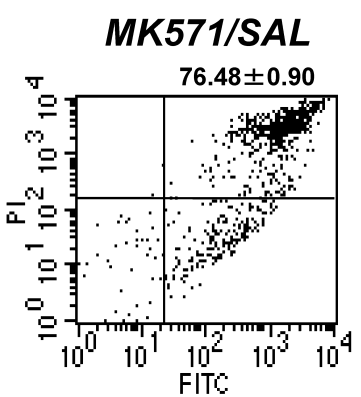

$5.72 \pm 1.2117 .60 \pm 0.33$

Fig. 3. Inhibition of SAL-Induced PS Externalization in Raji Cells by CsA

Raji cells were preincubated in the presence or absence of CsA $4 \mu \mathrm{M}$ or MK571 $20 \mu \mathrm{M}$. After washing, the cells were incubated with SAL $(10 \mu \mathrm{g} / \mathrm{ml})$ at $4{ }^{\circ} \mathrm{C}$ for $30 \mathrm{~min}$. Annexin V-bound versus PI-incorporated cells was analyzed using FACScan. Numbers show the percentage of cells divided into the LL quadrant, LR quadrant, and UR quadrant, respectively. Each value represents the mean \pm S.E. of three independent experiments performed in triplicate. $* p<0.05$ versus SAL-treated groups (indicated by "SAL").

The related items of SAL-induced PS externalization are summarized in Table 2. Although SAL bound to Gb3-expressing cells and induced PS externalization and cell shrinkage, the effect of SAL was not seen in Gb3-negative cell lines, i.e., these events were attributable to the binding of SAL to Gb3 on the cell surface. Pohl et al. reported that MDR1 P-gp was utilized for PS externalization in EPG85257 human gastric carcinoma cells overexpressing MDR1 P$\mathrm{gp},{ }^{23)}$ but they made no mention of the expression of MRP1 on the cells. Since MDR1 P-gp, together with MRP1, was present on Raji cells (see Fig. 4), it is possible that SAL selects and activates MDR1 P-gp among many molecules involved in PS externalization.

SAL Facilitates Drug Efflux Mediated Not Only by MDR1 P-gp But Also by MRP1 in Raji Cells Because SAL activated MDR1 P-gp-mediated PS externalization in Raji cells (Fig. 3), we investigated whether SAL accelerates drug efflux from Rho123- and 5-CFDA-loaded cells. Although the residual amount of Rho123 in Rho123-loaded K562/DXR cells decreased in a time-dependent manner in the presence of MDR1 P-gp (Figs. 5, 6), most of the incorporated Rho123 was not released from Raji and K562 cells during 60 min without CsA (Fig. 5). On the other hand, 5-CFDA was easily released from all cell lines that retained MRP1 (Figs. 5 and 2B). The liberation of Rho123 and 5-CFDA from Rho123- and 5-CFDA-loaded cells was inhibited by the addition of CsA and MK571, respectively (Fig. 5).

Since the expression of MDR1 P-gp was very low in Raji cells, they did not discharge incorporated Rho123. Treatment of Rho123-loaded Raji cells with SAL at $4{ }^{\circ} \mathrm{C}$ for $30 \mathrm{~min}$

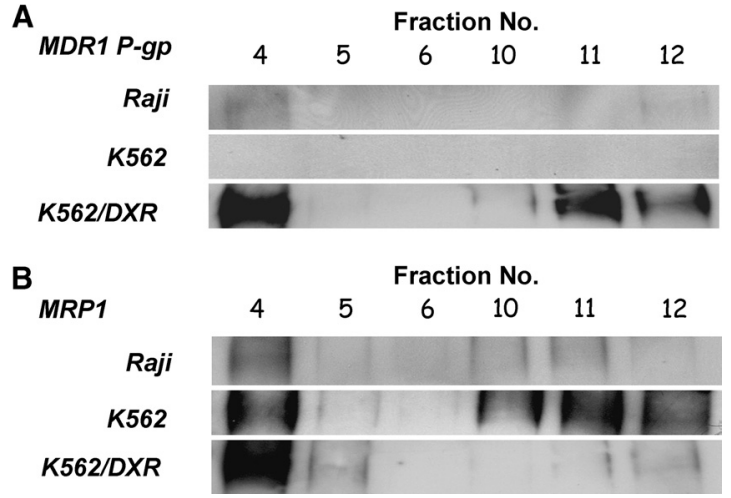

Fig. 4. Localization of $\mathrm{ABC}$ Transporter Proteins in Raji, K562, and K562/DXR Cells

After sucrose density-gradient centrifugation, each fraction (10 $\mu \mathrm{g}$ protein/lane) was separated by SDS-PAGE in $7.5 \%$ gel and transferred to PVDF membrane. The membranes were reacted with $\mathrm{C} 219$ mouse mAb directed against human MDR1 P-gp (A) and MRPr1 rat mAb directed against MRP1 (B), respectively. Then HRP-conjugated anti-mouse IgG and anti-rat IgG were used as secondary Abs, respectively, and visualized with chemiluminescence. Fraction numbers indicate of fr. $4-6$ and fr. $10-12$ obtained by sucrose density-gradient centrifugation, respectively.

caused an increase in the percentage of cells divided into the LL quadrant [Rho123 (-)/cell size (small)] from $11.30 \%$ to $29.90 \%$ (18.60\% increase, $p<0.05)$ (Fig. 6). Thus SAL facilitated MDR1 P-gp-induced Rho123 release from the cells with PS externalization. Similarly, 5-CFDA efflux from 5CFDA/MK571-loaded Raji cells was observed with SAL treatment. Treatment of 5-CFDA/MK571-loaded Raji cells with SAL increased the population in the LL quadrant from $12.40 \%$ to $58.78 \%$ (46.38\% increase, $p<0.001)$ (Fig. 6).

Only SAL-activated MDR1 P-gp caused PS externalization (Fig. 3), and these results suggest that SAL activates both the ABC transporters for efflux of Rho123 and 5-CFDA in Raji cells. In contrast, SAL did not activate MDR1 P-gp and MRP1 in K562 and K562/DXR cells (data not shown).

SAL Activates MDR1 P-gp Localized in the GEM in Raji Cells Because MDR1 P-gp participated in SAL-induced PS externalization, we studied the localization of MDR1 P-gp. It was observed that SAL binds to Gb3 localized in the GEM (Sugawara S., Ogawa Y., Hosono M., Takayanagi M., Taka H., Fujimura T., Murayama K., Hakomori S., Nitta K., unpublished observation). To confirm whether SAL-induced MDR1 P-gp activation occurs with the binding of SAL to Gb3 localized in the GEM of Raji cells, the GEM and soluble high-density fractions were separated by sucrose density-gradient centrifugation. MDR1 P-gp was recovered in the GEM (fr. 4) derived from Raji and K562/DXR cells but not from K562 cells. In the case of K562/DXR cells, MDR1 P-gp was also recovered in soluble high-density fractions (fr. 11, fr. 12) (Fig. 4A). On the other hand, MRP1 was recovered in the GEM derived from all three cell lines. In the case of K562 cells, MRP1 was detected not only in the GEM but also in fr. 10-12 (Fig. 4B). These results suggest that Gb3, MDR1 P-gp, and MRP1 are colocalized in the GEM, and that SAL binding to Gb3 specifically activates MDR1 P-gp.

It has been reported that MDR1 P-gp and MRP1 are predominantly located in the GEM of MDR cells such as doxorubicin-resistant MCF-7 (MCF-AdrR), ${ }^{42)} \mathrm{MCF}-7$ cells stably transfected with MDR1 P-gp (BC-19), ${ }^{42)}$ 2780AD cells, $\left.{ }^{43}\right)$ and HT29 ${ }^{\text {col }}$ cells. $^{44)}$ Since caveolar constituents, such as 


\section{Rho123-loaded cells}

Raji

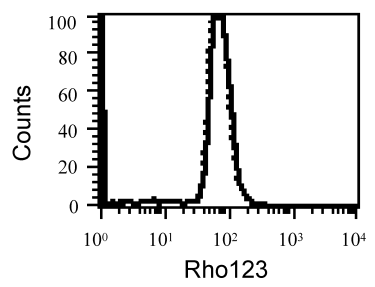

5-CFDA-loaded cells

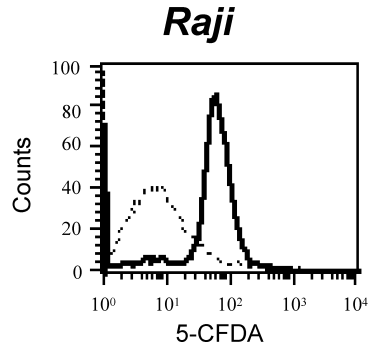

K562

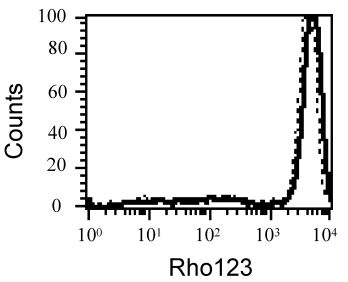

K562

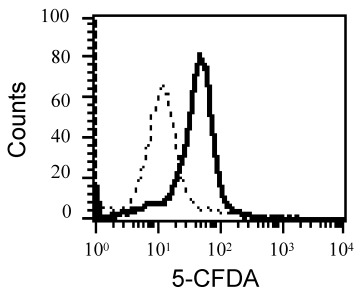

K562/DXR

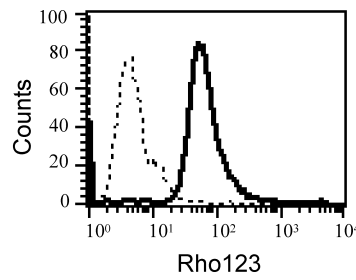

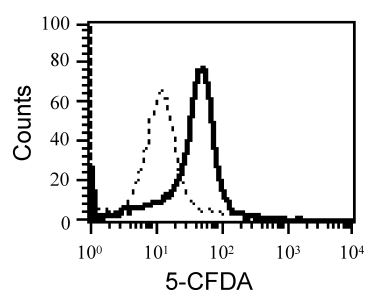

Fig. 5. Outward Transport of Rho123 and 5-CFDA in Raji, K562, and K562/DXR Cells

After cells were loaded with Rho1 23 or 5 -CFDA at $37^{\circ} \mathrm{C}$ for $60 \mathrm{~min}$, the cells were incubated in the presence (solid line) or absence (dotted line) of CsA $20 \mu \mathrm{M}$ or MK571 $80 \mu \mathrm{M}$ at $37^{\circ} \mathrm{C}$ for $60 \mathrm{~min}$. The residual amounts of Rho123 and 5-CFDA were analyzed using flow cytometry.

A

\section{Rho123-loaded cells without SAL}

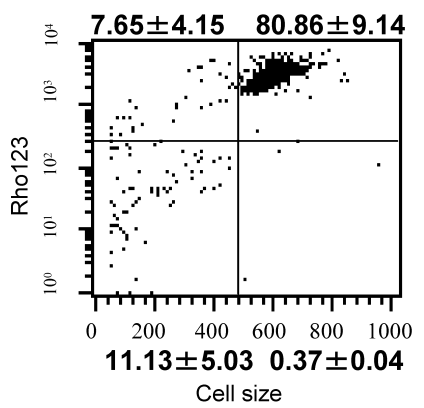

\section{5-CFDA-loaded cells} without SAL

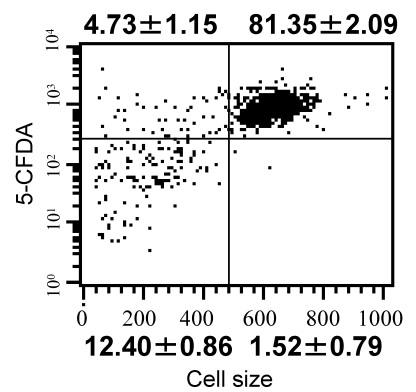

with SAL

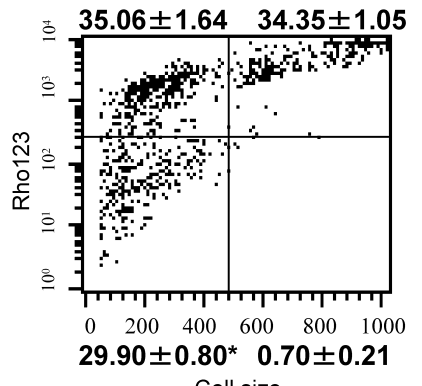

Cell size

with SAL
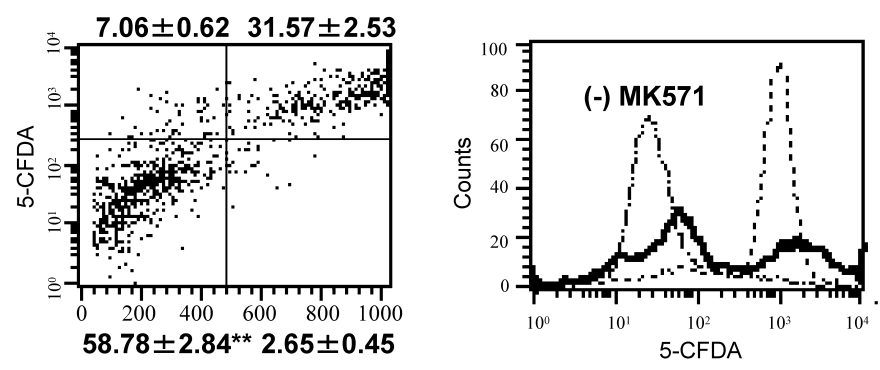

Fig. 6. Evaluation of MDR1 P-gp- or MRP1-Mediated Drug Efflux in Raji Cells by SAL

Both Rho123- and 5-CFDA-loaded Raji cells were prepared using the same method as described in Fig. 5. Because a large percentage of 5-CFDA was released from the 5CFDA-loaded cells during 60-min incubation, they were preincubated with MK571 for the preservation of 5-CFDA in them (5-CFDA/MK571-loaded cells) before SAL treatment. Rho123- or 5-CFDA/MK571-loaded cells were incubated with (solid line) or without (dotted line) SAL ( $10 \mu \mathrm{g} / \mathrm{ml})$ at $4{ }^{\circ} \mathrm{C}$ for $30 \mathrm{~min}$. The residual amounts of Rho123 and 5CFDA and cell size were analyzed using flow cytometry. (A) Rho123/5-CFDA content versus cell size dot plots; (B) Rho123/5-CFDA fluorescence histograms. Each value represents the mean \pm S.E. of three independent experiments performed in triplicate. $* p<0.05$ and $* * p<0.001$ versus control groups (indicated by “without SAL"), respectively. 
caveolin, were up-regulated in MCF-AdrR cells, but not in BC-19 cells, ${ }^{42}$ and since MDR1 P-gp was carried in the chemotherapeutic agent-sensitive Raji cells described here, further studies are required for the analysis of the constituents of the GEM in Raji cells. In addition, because the localization and function of MDR1 P-gp are influenced by cholesterol depletion, ${ }^{45)}$ it is suggested that SAL-induced PS externalization accompanies cholesterol movement.

In conclusion, our results demonstrate for the first time that SAL, a rhamnose-binding lectin, selectively binds to Gb3 on the surface of Gb3-expressing cells and leads to activation of MDR1 P-gp, causing regulation of PS externalization (phospholipid asymmetry) and induction of a cell volume decrease.

Acknowledgment We thank Dr. Senitiroh Hakomori for his helpful discussion.

\section{REFERENCES AND NOTE}

1) Vermes I., Haanen C., Steffens-Nakken H., Reutelingsperger C., J. Immunol. Methods, 184, 39-51 (1995).

2) Boucher C., Gobeil S., Samejima K., Earnshaw W. C., Poirier G. G., Methods Cell Biol., 66, 289-306 (2001).

3) Kaufmann S. H., Mesner P. W., Jr., Samejima K., Tone S., Earnshaw W. C., Methods Enzymol., 322, 3-15 (2000).

4) Vu C. C., Bortner C. D., Cidlowski J. A., J. Biol. Chem., 276, $37602-$ 37611 (2001).

5) Rabinovich G. A., Modesti N. M., Castagna L. F., Landa C. A., Riera C. M., Sotomayor C. E., J. Biochem. (Tokyo), 122, 365-373 (1997).

6) Devaux P. F., Biochemistry, 30, 1163-1173 (1991).

7) Fadeel B., Gleiss B., Hogstrand K., Chandra J., Wiedmer T., Sims P. J., Henter J. I., Orrenius S., Samali A., Biochem. Biophys. Res. Commun., 266, 504-511 (1999).

8) Bratton D. L., Fadok V. A., Richter D. A., Kailey J. M., Guthrie L. A., Henson P. M., J. Biol. Chem., 272, 26159-26165 (1997).

9) van Helvoort A., Smith A. J., Sprong H., Fritzsche I., Schinkel A. H., Borst P., van Meer G., Cell, 87, 507-517 (1996).

10) Vento R., Giuliano M., Lauricella M., Carabillo M., Di Liberto D., Tesoriere G., Mol. Cell. Biochem., 185, 7-15 (1998).

11) Liu S., Kawai K., Tyurin V. A., Tyurina Y. Y., Borisenko G. G., Fabisiak J. P., Quinn P. J., Pitt B. R., Kagan V. E., Biochem. J., 354, 397-406 (2001)

12) Shvedova A. A., Tyurina J. Y., Kawai K., Tyurin V. A., Kommineni C., Castranova V., Fabisiak J. P., Kagan V. E., J. Invest. Dermatol., 118, 1008-1018 (2002).

13) Kageyama A., Kusano I., Tamura T., Oda T., Muramatsu T., Biosci. Biotechnol. Biochem., 66, 835-839 (2000).

14) Ohba H., Moriwaki S., Bakalova R., Yasuda S., Yamasaki N., Toxicol. Appl. Pharmacol., 195, 182-193 (2004).

15) Hajto T., Berki T., Boldizsar F., Nemeth P., Immunol. Lett., 86, 23-27 (2003).

16) Dias-Baruffi M., Zhu H., Cho M., Karmakar S., McEver R. P., Cummings R. D., J. Biol. Chem., 278, 41282-41293 (2003).

17) Hosono M., Ishikawa K., Mineki R., Murayama K., Numata C.,
Ogawa Y., Takayanagi Y., Nitta K., Biochim. Biophys. Acta, 1472, $668-675$ (1999).

18) Hosono M., Kawauchi H., Nitta K., Takayanagi Y., Shiokawa H., Mineki R., Murayama K., Biol. Pharm. Bull., 16, 1-5 (1993).

19) Sugawara S., Hosono M., Ogawa Y., Takayanagi M., Nitta, K., Trends Glycosci. Glycotech., 16 (Suppl.), S46 (2004).

20) Mangeney M., Lingwood C. A., Taga S., Caillou B., Tursz T., Wiels J., Cancer Res., 53, 5314-5319 (1993).

21) Furukawa K., Yokoyama K., Sato T., Wiels J., Hirayama Y., Ohta M., Furukawa K., J. Biol. Chem., 277, 11247-11254 (2002).

22) Martin S. J., Reutelingsperger C. P., McGahon A. J., Rader J. A., van Schie R. C., LaFace D. M., Green D. R., J. Exp. Med., 182, 15451556 (1995).

23) Pohl A., Lage H., Müller P., Pomorski T., Herrmann A., Biochem. J., 365, 259-268 (2002).

24) Frasch S. C., Henson P. M., Kailey J. M., Richter D. A., Janes M. S., Fadok V. A., Bratton D. L., J. Biol. Chem., 275, 23065-23073 (2000).

25) Gleiss B., Gogvadze V., Orrenius S., Fadeel B., FEBS Lett., 519, 153 158 (2002).

26) Toti F., Schindler V., Riou J. F., Lombard-Platet G., Fressinaud E., Meyer D., Uzan A., Le Pecq J. B., Mandel J. L., Freyssinet J. M., Biochem. Biophys. Res. Commun., 241, 548-552 (1997).

27) Wunderlich K., Zimmerman C., Gutmann H., Teuchner B., Flammer J., Drewe J., Mol. Vis., 9, 756-761 (2003).

28) Primers for G3PDH attached to M-MLV RT-PCR high (Toyobo) were used.

29) Zhou Q., Sims P. J., Wiedmer T., Blood, 92, 1707-1712 (1998).

30) Hakomori S., Handa K., Methods Enzymol., 363, 191-207 (2003).

31) Laemmli U. K., Nature (London), 227, 680-685 (1970).

32) Towbin H., Staehelin T., Gordon J., Proc. Natl. Acad. Sci. U.S.A., 76, $4350-4354$ (1979).

33) Jablonski E. M., Webb A. N., McConnell N. A., Riley M. C., Hughes F. M., Jr., Am. J. Physiol. Cell Physiol., 286, C975-C985 (2004).

34) Kawagishi C., Kurosaka K., Watanabe N., Kobayashi Y., Biochim. Biophys. Acta, 1541, 221-230 (2001).

35) Borst P., Zelcer N., van Helvoort A., Biochim. Biophys. Acta, 1486, $128-144$ (2000).

36) Zhao J., Zhou Q., Wiedmer T., Sims P. J., J. Biol. Chem., 273, 66036606 (1998).

37) Mouro I., Halleck M. S., Schlegel R. A., Mattei M. G., Williamson P., Zachowski A., Devaux P., Cartron J. P., Colin Y., Biochem. Biophys. Res. Commun., 257, 333-339 (1999).

38) Grandjean F., Bremaud L., Verdier M., Robert J., Ratinaud M. H., Anticancer Drugs, 12, 247-258 (2001).

39) Klappe K., Hinrichs J. W., Kroesen B. J., Sietsma H., Kok J. W., Int. J. Cancer, 110, 511-522 (2004).

40) Minamikawa T., Williams D. A., Bowser D. N., Nagley P., Exp. Cell Res., 246, 26-37 (1999).

41) Bradham C. A., Qian T., Streetz K., Trautwein C., Brenner D. A., Lemasters J. J., Mol. Cell Biol., 18, 6353-6364 (1998).

42) Lavie Y., Fiucci G., Liscovitch M., J. Biol. Chem., 273, 32380-32383 (1998).

43) Hinrichs J. W., Klappe K., Hummel I., Kok J. W., J. Biol. Chem., 279, 5734-5738 (2004)

44) Kok J. W., Veldman R. J., Klappe K., Koning H., Filipeanu C. M., Müller M., Int. J. Cancer, 87, 172-178 (2000).

45) Troost J., Lindenmaier H., Haefeli W. E., Weiss J., Mol. Pharmacol., 66, 1332-1339 (2004). 